\title{
Excess aluminum tolerance of the common water-hyacinth (Eichhornia crassipes) under greenhouse conditions
}

\author{
Fánor Casierra-Posada $^{1 *}$, Jeison Julián Arias-Salinas ${ }^{1}$, and Julián Felipe Rodríguez-Quiroz ${ }^{1}$ \\ ${ }^{1}$ Universidad Pedagógica y Tecnológica de Colombia, Grupo de Investigación Ecofisiología Vegetal, Avenida Central del Norte \\ No.39-115, Tunja, Colombia. "Corresponding author (fanor.casierra@uptc.edu.co).
}

Received: 28 April 2021; Accepted: 20 July 2021; doi:10.4067/S0718-58392021000400597

\begin{abstract}
Aluminum is a heavy metal toxic to living organisms and is released into soils with a strong acidic composition. The floating aquatic weed Eichhornia crassipes (Mart.) Solms is reported as the most widespread invasive vascular plant in the world and is distributed all over Colombia ranging from sea level to the cold Andean highlands. As a consequence of the solubility of $\mathrm{Al}^{3+}$ in soils, it flows into fresh water sources where $E$. crassipes grows as an invasive plant. A greenhouse study was conducted in Tunja, Colombia, with the objective of evaluating the growth of aquatic weed in an aqueous substrate with $\mathrm{Al}^{3+}$ content similar to those recorded in lakes $\left(0.0,0.2,0.4,0.6\right.$, and $\left.0.8 \mathrm{mg} \mathrm{L}^{-1} \mathrm{Al}^{3+}\right)$. Biomass production, leaf area, evapotranspiration, water use efficiency, and other allometric variables were evaluated. An increase of $18.2 \%$ in the transpiration rate and a reduction between $9.7 \%-41.8 \%$ in the leaf area were found. The latter reduced the value of variables such as the specific leaf area between 9.9\%-34.6\% and leaf area ratio between 16.7\%-40.4\%. However, the total dry weight, DM partitioning, root to shoot ratio, leaf weight ratio, and the absolute and relative growth rates did not show significantly different values between treatments. Therefore, $\mathrm{Al}$ content found in water sources in Colombia, despite being in the ranges reported as toxic for some aquatic plants, did not significantly affect the growth of E. crassipes due to its phenotypic plasticity and anthropic alteration of water sources but rather favor its growth.
\end{abstract}

Key words: Aquatic weed, evapotranspiration, growth, invasive plant, stress, toxicity.

\section{INTRODUCTION}

In Colombia, around 67 million hectares of land have acidity problems which causes increased risk of Al toxicity to all living things, including plants (Casierra-Posada et al., 2008). When soils have a slightly acidic to neutral composition, the naturally occurring $\mathrm{Al}$ that is part of the soil would not pose any threat to living things; however, under strongly acidic conditions, this metal is released and is available in solution within the soil, making it toxic (Casierra-Posada and NiñoMedina, 2007). Once in solution within the soil, $\mathrm{Al}^{3+}$ can migrate and contaminate water sources. In a study carried out in a Colombian region characterized by strongly acidic soils, a value of $0.14 \mathrm{mg} \mathrm{L}^{-1} \mathrm{Al}^{13+}$ was recorded in the water of one of its lakes (Morales Velasco and Salazar Sánchez, 2012). Thus, dissolved Al in freshwater sources represents a risk of toxicity to the biota of rivers and lakes.

Heavy metal toxicity limits plant growth in many environments. Certain metals such as $\mathrm{Cu}$ and $\mathrm{Zn}$, are essential micronutrients for plants in low concentrations, but they can become toxic when their concentration exceeds the tolerance levels of plants. On the other hand, metals such as $\mathrm{Al}$ and $\mathrm{Pb}$ are only known for their toxicity (Hodson, 2012). Although $\mathrm{Al}$ is one of the most abundant elements in the earth's crust, it is toxic to many plants when the concentration is greater than 2 to $3 \mathrm{mg} \mathrm{kg}^{-1}$ and soil with a $\mathrm{pH}$ of 5.5 (Balsberg Pahlsson, 1990). 
In relation to the effect of $\mathrm{Al}^{3+}$ in plantlets, it has been found that when seedlings of Crambe abyssinica are exposed to $\mathrm{Al}^{3+}$, the damage caused to its development was more severe as the concentration of $\mathrm{Al}^{3+}$ increased in the substrate. Thus, as a consequence of exposure to $\mathrm{Al}^{3+}$, decreased growth, biomass accumulation and leafiness, as well as changes observed in DM partitioning in the different organs of the plants were seen (Colodetti et al., 2015). Additionally, it is reported that the presence of $\mathrm{Al}$ in the substrate reduces the percentage of germination in seeds of Triticum aestivum and Zea mays, by $31 \%$ and $15 \%$, respectively (Casierra-Posada et al., 2008).

The floating aquatic weed Eichhornia crassipes (Mart.) Solms is reported as the most widespread invasive vascular plant in the world and is distributed all over Colombia from sea level to the cold zone (around $3000 \mathrm{~m}$ a.s.l.) The plant has a strong impact on the physical-chemical properties of fresh water sources in which it causes alterations in temperature, $\mathrm{pH}$, biological oxygen demand, and nutrient levels. Sometimes it induces a complete decrease in dissolved oxygen in the water which causes the death of a large number of aquatic organisms (Téllez et al., 2008).

Eichhornia crassipes has been seen as a useful or harmful plant in ecosystems. Almeida et al. (2021) mentions that this plant causes serious problems and is therefore necessary to eliminate it from aquatic ecosystems which would have a huge environmental benefit. On the other hand, Ansari et al. (2020) and Sharma et al. (2021) suggest that because the quality of water is frequently altered by various organic and inorganic pollutants, various strategies have been developed to solve this problem. One technique utilizes phytoremediation with aquatic plants such as E. crassipes due to their capacity to adapt and tolerate different heavy metals and other types of pollutants. Additionally, the use of cellulose has been taken into consideration as an alternative for the treatment of water sources contaminated with heavy metals. This makes $E$. crassipes very important due to its natural levels of cellulose and its abundance in wetlands, polluted rivers, and lakes (Sayago et al., 2020).

Various studies have been carried out on the management and control of E.crassipes and use of its biomass (Ali et al., 2020). However, no studies related to the effect of $\mathrm{Al}$ on these plants are reported since studies on the effects of $\mathrm{Al}^{3+}$ as a stressor in freshwater macrophytes are particularly scarce, especially when compared with the large number of references available on the effects of this heavy metal on land plants (Gensemer and Playle, 1999). However, it has been mentioned that this invasive plant is very efficient in the elimination of a wide range of metals in water sources, among which is $\mathrm{Al}$, and it is pointed out that this aquatic weed can remove up to $73 \%$ of this metal in wastewater from steel effluents (Ali et al., 2020).

A significant correlation has been shown between low $\mathrm{pH}$ and high $\mathrm{Al}^{3+}$ concentration in acidified fresh water where this metal can reach levels of 0.3 to $1.6 \mathrm{mM}\left(0.008-0.043 \mathrm{mg} \mathrm{L}^{-1}\right)$ and cause a serious metabolic disorder in some hydrophytes (Dickson, 1978; Pettersson et al., 1985). However, it has been shown that in general, aquatic plants can withstand a high degree of pollutants present in sewage leachates without showing obvious signs of a significant reduction in biomass and growth rate (Ali et al., 2020). With this knowledge, the objective of this study was to evaluate the growth of the floating aquatic weed Eichhornia crassipes, under aqueous substrate conditions in which $\mathrm{Al}^{3+}$ was added in concentrations similar to those found in water sources surrounded by soils with strongly acidic compositions. This allowed its growth to be evaluated under controlled conditions that emulate the conditions that the natural environment offers in order to understand why this weed is such a successful plant in the invasion of water sources.

\section{MATERIALS AND METHODS}

The study was carried out in the glass greenhouse of the Universidad Pedagógica y Tecnológica de Colombia (UPTC),

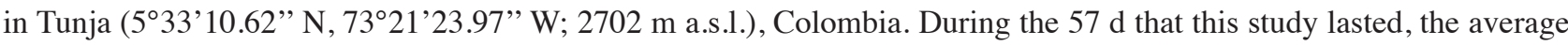
climatic conditions inside the greenhouse were $16.1 \pm 7.8{ }^{\circ} \mathrm{C}$ and $72.3 \pm 16.9 \%$ relative humidity. Common waterhyacinth plants (Eichhornia crassipes (Mart.) Solms, Pontederiaceae) were taken from the La Playa reservoir in Tuta $\left(5^{\circ} 41^{\prime} 14.41^{\prime \prime} \mathrm{N}, 73^{\circ} 15^{\prime} 14.81^{\prime} \mathrm{W} ; 2587 \mathrm{~m}\right.$ a.s.l.), Colombia. These plants are typically found in the open with an average temperature of $13 \pm 6^{\circ} \mathrm{C}$ and a relative humidity of $79 \pm 6 \%$.

In order to determine information about the growth of the plants at the beginning of the study, 20 out of 170 plants were specifically selected and measured based on their uniformity in terms of their size, leaf area, and total dry weight per plant. The remaining plants were placed in $700 \mathrm{~mL}$ containers with a solution containing distilled water and water taken from the La Playa reservoir in a 1:1 ratio. This mixture was used specifically so that the plants grew in an aqueous environment as similar as possible to their place of origin in terms of the microbiota in the water. 
Five days after placing them in the containers with the solution, the plants were distributed into five groups of 30 plants each. The containers were then labeled to identify them at the time of inducing excess Al. The criteria for selecting the treatments considered studies such as that of Abdullah (2014), which mentions that the content of $\mathrm{Al}^{3+}$ in natural waters is highly variable and dependent on physicochemical and mineralogical factors in the environment. The dissolved $\mathrm{Al}^{3+}$ in waters in which the $\mathrm{pH}$ is almost neutral usually oscillates between 0.001 and $0.05 \mathrm{mg} \mathrm{L}^{-1}$, but this range can reach values of $0.5-1.0 \mathrm{mg} \mathrm{L}^{-1}$ in acidic waters or those rich in organic matter. In cases of extreme acidity such as water sources affected by the acid drainage of mining operations; dissolved $\mathrm{Al}^{3+}$ content of up to $90 \mathrm{mg} \mathrm{L}^{-1}$ have been recorded. Studies in Colombia such as that by Morales Velasco and Salazar Sánchez (2012), determined the amount of $\mathrm{Al}^{3+}$ in lakes in Colombian areas consisting of geologically poorly evolved acidic soils containing a high amount of $\mathrm{Al}$ and low amounts of $\mathrm{Ca}$ and $\mathrm{P}$. Their study found a pH of 4.63 and an $\mathrm{Al}^{3+}$ content of $0.14 \mathrm{mg} \mathrm{L}^{-1}$ in the lake water. As a result, the evaluated treatments that would be applied consisted of 0.0 (control), 0.2, 0.4, 0.6, and $0.8 \mathrm{mg} \mathrm{L}^{-1} \mathrm{Al}^{3+}$ dissolved in water from $\mathrm{Al}(\mathrm{OH})_{3} \cdot 7 \mathrm{H}_{2} \mathrm{O}$ (Merck KGaA, Darmstadt, Germany).

Every $3 \mathrm{~d}$ the water that was considered evapotranspired was replenished so that the total amount of water was maintained at $700 \mathrm{~mL}$. Finally, with a pH meter ( $780 \mathrm{pH}$ Meter, Metrohm, Herisau, Switzerland) the $\mathrm{pH}$ of the solution was recorded in each of the containers. At the end of the study, $57 \mathrm{~d}$ after the start, the plants were removed from their containers and measurements were taken. The leaf area of each plant was determined using an integrated area meter (LI-3000-A, LI-COR, Lincoln, Nebraska, USA). Likewise, dry weight of leaves, petioles, and roots were determined by drying them in oven (UFE 500, Memmert, Schwabach, Germany) at $80{ }^{\circ} \mathrm{C}$ until reaching a constant dry weight. With this information, total dry weight per plant, DM partitioning, root to shoot ratio (R/S), leaf area ratio (LAR), specific leaf area (SLA), and leaf weight ratio (LWR) were calculated. Additionally, the absolute and relative growth rate in accordance with the methodology proposed by Hunt (1990) was calculated. The water use efficiency (WUE) was also calculated as the amount of DM as a function of the evapotranspired water per plant.

The plants were placed in the greenhouse using a completely random design with five treatments and 30 replicates per treatment, taking one plant as a replicate. Statistical analysis was performed using the IBM-SPSS version 26.0 application (IBM Corp., Armonk, New York, USA). An ANOVA was performed with Tukey's HSD (honest significant difference) test $(\mathrm{P}<0.05)$.

\section{RESULTS AND DISCUSSION}

\section{pH of the substrate}

At the beginning of the study, without having applied the aluminum hydroxide to the water, an average $\mathrm{pH}$ value of 6.68 \pm 0.05 was recorded. Since the reagent used to create excess $\mathrm{Al}$ was $\mathrm{Al}(\mathrm{OH})_{3} \cdot 7 \mathrm{H}_{2} \mathrm{O}$, this caused a slight increase in the $\mathrm{pH}$ value of the water in which the plants grew. At the end of the test, the aqueous substrate of the plants in the control treatment had a pH value of $4.46 \pm 0.14$. The $\mathrm{pH}$ value of the aqueous medium in which the plants treated with 0.2 and 0.4 $\mathrm{mg} \mathrm{L}^{-1} \mathrm{Al}^{3+}$ grew, increased by 0.12 and 0.18 units, respectively, above the average value found for the growth medium in control plants. Similarly, plants treated with 0.6 and $0.8 \mathrm{mg} \mathrm{L}^{-1} \mathrm{Al}^{3+}$ resulted in an increase in $\mathrm{pH}$ by 0.26 and 0.51 units respectively, above the average value of control. Therefore, plants of all treatments grew in a pH range of 4.46 to 4.97 , with a standard deviation of \pm 0.25 among all treatments.

Rodríguez-Zambrano and Aranguren-Riaño (2014) reported an average $\mathrm{pH}$ of $4.93 \pm 1.18$ for the water in the La Playa reservoir where the plants were obtained for the experiment. As a result, $\mathrm{pH}$ of the water from the reservoir of origin of the plantlets and that of the aqueous substrate in which the plants grew in the greenhouse show great similarity. So, growth of plants in this study was not limited by $\mathrm{pH}$, but as a consequence of the effect of $\mathrm{Al}^{3+}$ on the plants.

The $\mathrm{pH}$ of the medium in which E. crassipes plants grow is of great importance for their normal metabolism and therefore for their growth. Téllez et al. (2008) reports that this value should range between 6.0 and 8.0 and added that if the $\mathrm{pH}$ value of the medium in which the plants grow is outside this range, the plant will adjust the $\mathrm{pH}$ until it reaches a value close to its comfort range. The maximum growth of E. crassipes, in terms of number of plants and dry weight, occurs when $\mathrm{pH}$ is 7.0. A pH of 3.2 to 4.2 would be very toxic to the plant, while $\mathrm{pH}$ from 4.2 to 4.3 and 4.3 to 4.5 would cause an inhibitory and possibly inhibitory effect, respectively, to the plants (Berg, 1961). Additionally, Maessen et al. (1992) evaluated the effects of $\mathrm{pH}, \mathrm{Al}^{3+}$, and the $\mathrm{Al}^{3+} / \mathrm{Ca}^{2+}$ ratio on some species of acid-tolerant and intolerant aquatic plants and 
found that neither the addition of $\mathrm{Al}$ nor the values of $\mathrm{Al}^{3+} / \mathrm{Ca}^{2+}$ ratio had any visible effect on the vitality of the plants. These authors concluded that the disappearance of the plant species investigated in soft-water after acidification was not due to intoxication by $\mathrm{Al}$, but to a direct effect of the proton load of the environmental water.

In fact, according to Gensemer and Playle (1999), the most important environmental factor controlling $\mathrm{Al}^{3+}$ toxicity in algae is $\mathrm{pH}$. The solubility and specificity of $\mathrm{Al}^{3+}$ are directly controlled by $\mathrm{pH}$, so at a minimum, the total effect of nominal exposures to dissolved $\mathrm{Al}^{3+}$ will change as a function of $\mathrm{pH}$. Given this, $\mathrm{Al}^{3+}$ should be more toxic at lower $\mathrm{pH}$ values given exposure to a fixed amount of $\mathrm{Al}^{3+}$, because the presumably more toxic soluble forms of $\mathrm{Al}^{3+}$ become more and more abundant as pH fall below 5.5 (Casierra-Posada and Niño-Medina, 2007). Despite these reports, the growth of E. crassipes in the La Playa reservoir, where the $\mathrm{pH}$ of the water is $4.93 \pm 1.18$ has been observed without any inhibitory effect of $\mathrm{pH}$ on the growth of plants as reported by Berg (1961) and corroborated by the results of the current study.

\section{Effect of $\mathrm{Al}^{3+}$ on leaf area}

The average values of leaf area were inversely proportional to the increase in the content of $\mathrm{Al}^{3+}$ in the aqueous medium. Plants exposed to $0.4,0.6$, and $0.8 \mathrm{mg} \mathrm{L}^{-1} \mathrm{Al}^{3+}$ had a reduction in leaf area of $9.75 \%, 28.77 \%$, and $41.88 \%$, respectively, in relation to control plants (Figure 1), with differences that were significant. Colodetti et al. (2015) found that foliar area in Crambe abyssinica plants suffered a drastic reduction as a consequence of exposure to $\mathrm{Al}^{3+}$, a result that was observed even when plants were exposed to the lowest concentration of the metal studied in this experiment. Thus, these authors state that this variable resulted in an exponential decrease with increasing $\mathrm{Al}^{3+}$ concentration.

\section{Effect of $\mathrm{Al}^{3+}$ on evapotranspiration}

The amount of evapotranspired water increased only in plants exposed to $0.8 \mathrm{mg} \mathrm{L}^{-1} \mathrm{Al}$. In this treatment, the average evapotranspired water per plant was $18.27 \%$ greater than in control plants. Only this treatment presented significant differences with the other treatments including the control treatment (Figure 2). Bialowiec et al. (2014) mention that evapotranspiration and evaporation can cause the accumulation of pollutants. It can be inferred in the current study that intake and accumulation of $\mathrm{Al}$ in the aerial part of the plants increased by the joint action of the highest dose evaluated $\left(0.8 \mathrm{mg} \mathrm{L}^{-1} \mathrm{Al}^{3+}\right)$ and the evapotranspiration that increased with that level of the metal in the medium. However, despite these apparently unfavorable conditions for the plants, growth variables did not show significant differences, demonstrating the tolerance of E. crassipes plants to the $\mathrm{Al}^{3+}$ levels evaluated.

As a consequence of the toxic effect caused by heavy metals in plants, the photosynthetic apparatus is severely affected which alters stomatal conduction, rate of transpiration, and exchange of gases associated with internal $\mathrm{C}$. This can also influence the amount of pigments in the plastids, thereby affecting photosynthesis (Fu and Wang, 2015). Additionally, Dorneles et al. (2019) report $\mathrm{Al}^{3+}$ tolerant genotypes which show higher values of WUE and transpiration rate in control conditions (without being exposed to $\mathrm{Al}^{3+}$ ), compared to $\mathrm{Al}^{3+}$ sensitive genotypes.

Figure 1. Average value of leaf area in Eichhornia crassipes (Pontederiaceae) plants affected by Al in the aqueous substrate.

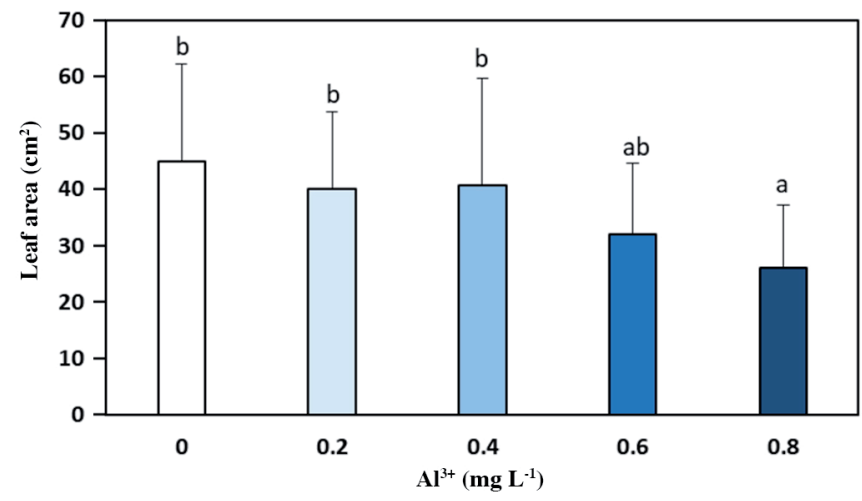

Different letters on the columns imply a significant difference according to Tukey's HSD test $(\mathrm{P}<0.05)$. Bars represent standard deviation. 
Figure 2. Average value of evapotranspiration in Eichhornia crassipes (Pontederiaceae) plants affected by Al in the aqueous substrate.

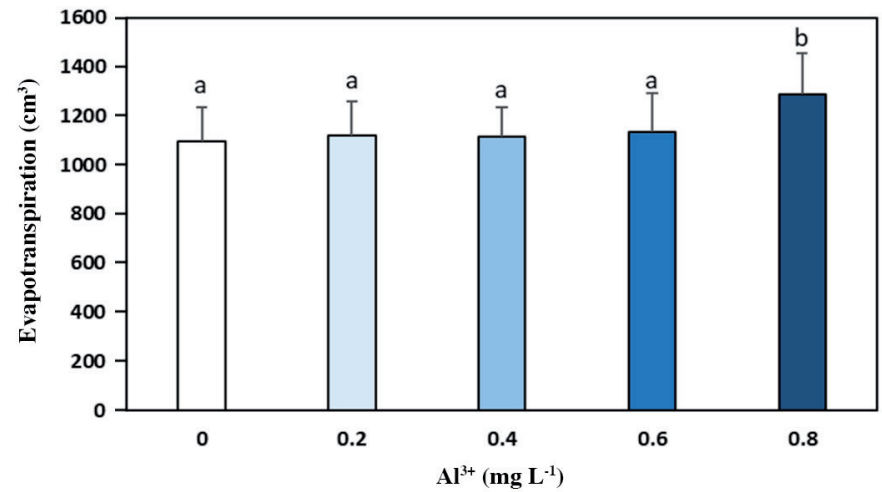

Different letters on the columns imply a significant difference according to Tukey's HSD test $(\mathrm{P}<0.05)$. Bars represent standard deviation.

Despite a reduction of the leaf area, an increase in the transpiration rate was observed which at first glance be incoherent; however, the great variability in the size of individual leaves and its compensation with the total number of leaves in a plant, have particularly important implications for understanding the adaptation strategy of plants to environmental changes (Wang et al., 2019). The reduction of leaf area under stressful conditions, could be understood as an adaptive morphological strategy, with the purpose of reducing the loss of water by transpiration or to slow down the growth in young leaves.

Small leaves have been found to have value in plants evolved for warm environments. This knowledge has the potential to enrich vegetation models, in which leaf temperature and water balance during photosynthesis play a key role and can potentially contribute to the understanding of biogeographic trends in relation to the size of leaves (Wang et al., 2019). Yates et al. (2010) point out that leaves of reduced size have thin boundary layers that facilitate transpiration in conditions of high humidity. Thus, high transpiration rates when water is available can facilitate the acquisition of nutrients. Leaves with a reduced area achieve a high transpiration capacity when the demand for evaporation is low and water is abundant. This can be a particularly important strategy for driving the flow of mass of nutrients to plant roots. This finding is of great relevance in the case of the current study since the $\mathrm{Al}$ stress induced in the E.crassipes plants stimulated the transpiration rate. This was especially the case with the highest concentration of the metal in order to transport the necessary nutrients to maintain plant growth despite the abiotic stress induced by $\mathrm{Al}^{3+}$, as observed in Table 1 .

Table 1. Average value of the variables involved in the growth of Eichhornia crassipes (Pontederiaceae) plants affected by $\mathrm{Al}$ in the aqueous substrate.

\begin{tabular}{lccccc}
\hline & \multicolumn{5}{c}{ Aluminum in aqueous solution $\left(\mathrm{mg} \mathrm{L}^{-1}\right)$} \\
\cline { 2 - 6 } Variable & $\begin{array}{c}0.0 \\
\text { (control) }\end{array}$ & 0.2 & 0.4 & 0.6 & 0.8 \\
\hline Total dry matter, g & $1.03 \mathrm{a}$ & $0.99 \mathrm{a}$ & $1.10 \mathrm{a}$ & $1.02 \mathrm{a}$ & $1.00 \mathrm{a}$ \\
Water use efficiency, $\mathrm{g} \mathrm{L}^{-1}$ & $0.94 \mathrm{a}$ & $0.89 \mathrm{a}$ & $0.98 \mathrm{a}$ & $0.91 \mathrm{a}$ & $0.79 \mathrm{a}$ \\
Relative growth rate, $\mathrm{g} \mathrm{g}^{-1} \mathrm{~d}^{-1}$ & $0.01 \mathrm{a}$ & $0.01 \mathrm{a}$ & $0.01 \mathrm{a}$ & $0.01 \mathrm{a}$ & $0.01 \mathrm{a}$ \\
Absolute growth rate, $\mathrm{g} \mathrm{d}^{-1}$ & $0.50 \mathrm{a}$ & $0.49 \mathrm{a}$ & $0.46 \mathrm{a}$ & $0.47 \mathrm{a}$ & $0.47 \mathrm{a}$ \\
Dry matter partitioning & & & & & \\
$\quad$ Leaves, \% & $22.86 \mathrm{a}$ & $22.36 \mathrm{a}$ & $21.01 \mathrm{a}$ & $21.42 \mathrm{a}$ & $21.32 \mathrm{a}$ \\
Petioles, \% & $37.09 \mathrm{a}$ & $37.02 \mathrm{a}$ & $36.42 \mathrm{a}$ & $37.11 \mathrm{a}$ & $35.59 \mathrm{a}$ \\
$\quad$ Roots, \% & $40.04 \mathrm{a}$ & $40.61 \mathrm{a}$ & $42.56 \mathrm{a}$ & $41.45 \mathrm{a}$ & $43.07 \mathrm{a}$ \\
Leaf weight ratio & $0.22 \mathrm{a}$ & $0.22 \mathrm{a}$ & $0.21 \mathrm{a}$ & $0.21 \mathrm{a}$ & $0.21 \mathrm{a}$ \\
Root to shoot ratio & $0.67 \mathrm{a}$ & $0.69 \mathrm{a}$ & $0.75 \mathrm{a}$ & $0.73 \mathrm{a}$ & $0.77 \mathrm{a}$ \\
\hline
\end{tabular}

Means with same letters showed nonsignificant difference according to Tukey's HSD test $(\mathrm{P}<0.05)$. Bars represent standard deviation. 
The loss of large volumes of freshwater as a consequence of their invasion by E. crassipes, can be three times higher in lakes when compared to these water sources without the presence of this aquatic weed. The increase in water loss through evapotranspiration caused by this plant is considered one of the most important aquatic weed problems in freshwater sources. The loss of water by evapotranspiration caused by this floating plant when covering an area greater than $20 \%$ of the water surface can be greater than $8000 \mathrm{~m}^{3} \mathrm{~d}^{-1}$ (Sasaqi et al., 2019). In accordance with the results of the current study, the presence of dissolved $\mathrm{Al}$ in the water of rivers and lakes would increase the evapotranspiration rate (Figure 2), which would compound the impact of this weed on water sources.

\section{Leaf area ratio reduction}

The value found for the leaf area ratio (LAR) decreased inversely proportional to the increase in the $\mathrm{Al}$ content in the water, with significant differences. Statistically, the values found in plants exposed to $0.4,0.6$, and $0.8 \mathrm{mg} \mathrm{L}^{-1} \mathrm{Al}^{3+}$ stand out, which had LAR values of $16.71 \%, 26.33 \%$, and $40.41 \%$, respectively, below the values of control plants at the end of the study (Figure 3). Considering that total dry weight per plant had nonsignificant difference, it can be inferred that the reduction in LAR was a consequence of a decrease in foliar area because of the increasing concentration of $\mathrm{Al}^{3+}$ in the water.

Since the LAR indicates the efficiency with which a plant uses its leaves to produce plant material; LAR shows the ability of a plant to form a photosynthetic surface. In Paulownia spp. plants, this value increased slightly after treatment with the highest concentrations of $\mathrm{Cd}$ and $\mathrm{Pb}$, but when the plants were exposed to increasing levels of $\mathrm{Zn}$, there was a reduction in LAR (Miladinova et al., 2014). In contrast, Kabir et al. (2010) found that LAR had an inversely proportional behavior in Thespesia populnea plants exposed to different concentrations of $\mathrm{Pb}$. In the particular case of $\mathrm{Al}$ toxicity, Colodetti et al. (2015) found that the LAR recorded in Crambe abyssinica plants exposed to increasing Al concentrations decreased with the addition of the metal up to a concentration of $78 \mathrm{mg} \mathrm{Al}^{3+} \mathrm{dm}^{-3}$. After that concentration, a small increase in the value of LAR was observed. These authors point out that toxicity of $\mathrm{Al}$ induces a competition between the development of the foliar area and DM production in the plants under study. As a result, only slightly higher values were recorded at high concentrations of $\mathrm{Al}^{3+}$ due to the severe problems caused by $\mathrm{Al}^{13+}$ to biomass production which becomes more serious than the damage caused in foliar area.

\section{Decrease in the value of specific leaf area}

The specific leaf area (SLA) ratios obtained at the end of the study were significantly reduced as $\mathrm{Al}$ content increased in the aqueous medium in which the plants grew. In plants treated with $0.4,0.6$, and $0.8 \mathrm{mg} \mathrm{L}^{-1} \mathrm{Al}$, SLA was reduced to $9.90 \%, 21.01 \%$, and $34.61 \%$, respectively, compared to control plants (Figure 4). Likewise, Colodetti et al. (2015) found that SLA in C. abyssinica plants decreased with the addition of $83 \mathrm{mg} \mathrm{Al}^{3+} \mathrm{dm}^{-3}$; beyond that value, SLA increased slightly. These authors explain this finding with the fact that exposure to $\mathrm{Al}^{3+}$ induces thicker and irregularly shaped leaves. When $\mathrm{Al}^{3+}$ content is increased, the formation of leaves is affected and the few leaves that develop accumulate very little biomass causing an increase in the values of specific leaf area.

Figure 3. Average leaf area ratio calculated in Eichhornia crassipes (Pontederiaceae) plants affected by Al in the aqueous substrate.

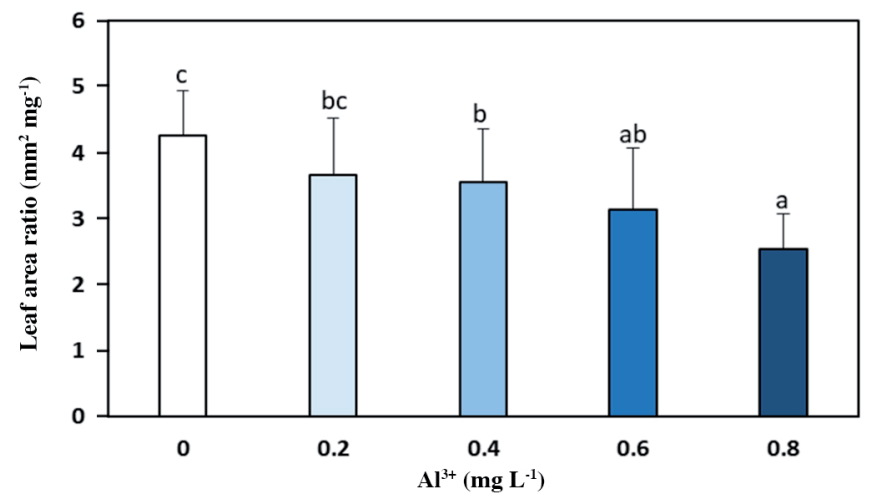

Different letters on the columns imply a significant difference according to Tukey's HSD test $(\mathrm{P}<0.05)$. Bars represent standard deviation. 
Figure 4. Average value of the specific leaf area calculated in Eichhornia crassipes (Pontederidaceae) plants affected by aluminum in the aqueous substrate.

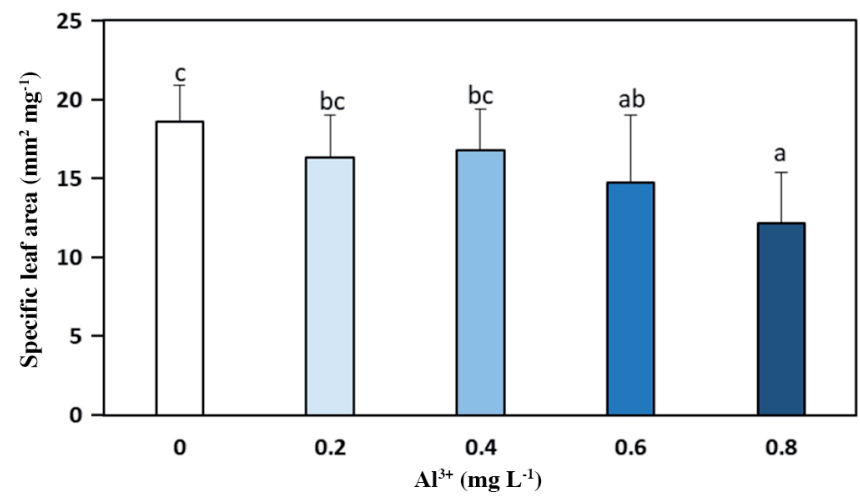

Different letters on the columns imply a significant difference according to Tukey's HSD test $(\mathrm{P}<0.05)$. Bars represent standard deviation.

\section{Variables unaffected by $\mathrm{Al}^{3+}$}

The variables which were analyzed in response to the treatments included total DM per plant, WUE, relative growth rate (RGR), absolute growth rate (AGR), DM partitioning in the different organs of the plants, and LWR and R/S. There was nonsignificant difference in any of these variables. The standard deviation for all the treatments, of each variable, was 0.04 $\mathrm{g}$ for total DM per plant, $0.2 \mathrm{~g} \mathrm{~L}^{-1}$ for WUE, $0.002 \mathrm{~g} \mathrm{~g}^{-1} \mathrm{~d}^{-1}$ for RGR, and $0.07 \mathrm{~g} \mathrm{~d}^{-1}$ for AGR. The DM partitioning in the different organs of the plants showed a standard deviation value of $3.1 \%$ for leaves, $4.4 \%$ for petioles, and $5.6 \%$ for roots. Likewise, a standard deviation of 0.03 was found for LWR value and 0.1 for R/S (Table 1). These results indicate that $E$. crassipes plants have a high phenotypic plasticity which allows them to tolerate high $\mathrm{Al}$ levels in the water where they grow. While some metals are toxic to plants only in high concentrations, others such as $\mathrm{Al}$, are only known for their toxic effect on plants (Hodson, 2012). In fact, according to Broadley et al. (2007), heavy metals can affect plants in many ways and the consequences of exposure to these metals are unpredictable and depend on factors such as the type of ion and its concentration, combinations of the different elements in the environment of the plant, the plant, and its development stage.

Gensemer and Playle (1999) point out that in the case of submerged aquatic plants, the probable site of $\mathrm{Al}^{3+}$ absorption is the root system. There is also the possibility of some absorption through the leaves in particular cases, however this is not the case since it is a floating plant. The absorption of $\mathrm{Al}^{3+}$ in E. crassipes occurs through the roots since they are submerged in the aqueous medium as mentioned by Ali et al. (2020). Ali et al. (2020) also point out that the active transport of heavy metals in free-floating aquatic plants occurs from roots where the metals are transferred to other parts of the plant's body. Passive transport is associated with the direct contact of the plant body with the polluting environment. In passive transport, heavy metals accumulate mainly in the upper parts of the plant. According to Gensemer and Playle (1999), in general there is little evidence that $\mathrm{Al}^{3+}$ itself has any influence on the community structure of macrophyte species, even in acidified lakes with higher concentrations of $\mathrm{Al}^{3+}$. Aluminum tolerant plants are also likely to be $\mathrm{H}^{+}$ tolerant plants, with $\mathrm{pH}$ as the main variable. Some species will bioaccumulate $\mathrm{Al}^{3+}$ and plants in the most acidic sites generally contain the highest tissue content.

\section{Tolerance of plants to $\mathrm{Al}^{3+}$}

The first noticeable symptom of toxicity, after the plants are exposed to $\mathrm{Al}^{3+}$ is a reduction of root growth (Casierra-Posada and Aguilar-Avendaño, 2007). Similarly, Pereira (2018) mentions that tolerance to $\mathrm{Al}^{3+}$ in Triticum aestivum is evaluated mainly in hydroponic solutions which expose the plants to solutions with and without this metal as the dependent variables. The relative length of root, the relative weight of root, and regrowth of root which are indicators of tolerance to $\mathrm{Al}^{3+}$ were evaluated. As a result, the tolerance of E. crassipes can be inferred since DM assigned to the roots did not show significant differences (Table 1). Additionally, a widely known symptom in plants exposed to $\mathrm{Al}^{3+}$ is a reduction in production of DM in the roots. Therefore, Freitas et al. (2016) used this parameter to evaluate tolerance to $\mathrm{Al}^{3+}$ in rice plants grown in nutrient solution. These authors also point out that before the decrease in DM content in the root occurs as a consequence of $\mathrm{Al}^{3+}$, this phytotoxic metal first reduces the elongation of the root resulting in shorter roots. 
In the current study, nonsignificant difference was found in DM partitioning or in total DM content per plant (Table 1) which is another way of determining the tolerance of E. crassipes plants to the harmful effects of Al. Freitas et al. (2016) used root and shoot DM production as variables to determine tolerance of rice plants grown in nutrient solutions with and without $\mathrm{Al}^{3+}$.

Using a hydroponic system with a nutrient solution, Dorneles et al. (2019) identified $\mathrm{Al}^{3+}$ tolerant Solanum tuberosum genotypes that presented higher WUE and transpiration rates in control treatments when compared to $\mathrm{Al}^{3+}$ sensitive plant materials. The current study did not show significant differences in WUE, but it did increase transpiration, especially with exposure of plants to $0.8 \mathrm{mg} \mathrm{L}^{-1} \mathrm{Al}^{3+}$. Consequently, these results also support that studied plants have sufficient phenotypic plasticity to tolerate the negative effects of $\mathrm{Al}^{3+}$.

In accordance with the proposals by Hunt et al. (2002), growth rates are fundamental variables to quantify biological productivity and evaluate the form and function of plants exposed to a demanding environmental supply. Similarly, Ludwig et al. (2010) point out that RGR is a relevant tool to infer the adaptation of plants that develop in stressful environments given that RGR is an indicator of efficiency.

Nascimento et al. (2016) evaluated the effect of a soil contaminated with $\mathrm{Pb}^{2+}$ on four cultivated species. The similarity of $\mathrm{Pb}^{2+}$ with $\mathrm{Al}^{3+}$ is that both are considered heavy metals. In their study, related to the RGR, these authors found that when growth rates are correlated with other growth data, it can be inferred that the negative values of RGR and net assimilation rate represent the consumption of reserves to satisfy a greater demand for energy for the maintenance of the plant created by the stress caused by this heavy metal. This shows that, under field conditions, the species in which these growth variables were negatively affected do not have the same tolerance as those in which these variables remained unaltered by $\mathrm{Pb}^{2+}$. Therefore, RGR and AGR are a determining tool when evaluating tolerance of plant species. Consequently, tolerance of E. crassipes to $\mathrm{Al}^{3+}$ concentrations evaluated in the current study can be assumed, based on the fact that nonsignificant difference was found in RGR, AGR, and DM partitioning (Table 1).

A significant correlation has been shown between low $\mathrm{pH}$ and high $\mathrm{Al}^{3+}$ concentrations in acidified fresh water where this metal can reach levels of 0.3 to $1.6 \mathrm{mM}\left(0.008-0.043 \mathrm{mg} \mathrm{L}^{-1}\right)$ and cause a serious metabolic disorder in some hydrophytes (Dickson, 1978; Pettersson et al., 1985). However, in the current study, floating plants of E. crassipes showed inversely proportional effects to the content of $\mathrm{Al}^{3+}$ in the aqueous substrate, in variables such as leaf area (Figure 2), LAR (Figure 3), and SLA (Figure 4). Despite these effects caused by Al, total dry weight, growth rates, and WUE were unaffected (Table 1). Ali et al. (2020) pointed out that many aquatic plants have the ability to resist a high load of toxic metals present in polluted waters without showing apparent signs of a significant reduction in the production and accumulation of biomass, nor a decrease in values of the variables involved in the evaluation of plant growth. Therefore, the adaptive success of this aquatic weed is a result of its phenotypic plasticity, fostered by the anthropic alteration of the physicochemical composition of water sources.

\section{CONCLUSIONS}

Among the variables evaluated, the variable affected the greatest due to the addition of $\mathrm{Al}^{3+}$ was leaf area, which also affected the values of the variables associated with growth. However, the plants were able to adapt through an increase in the evapotranspiration rate in order to increase the uptake of nutrients in addition to the water uptake by the roots. This helped maintain the values of growth rates, water use efficiency, and DM accumulation despite the stress conditions induced by the presence of $\mathrm{Al}^{3+}$. On the other hand, $\mathrm{Al}$ content found in water sources in Colombia, despite being in the ranges reported as toxic for some aquatic plants, did not significantly affect the growth of Eichhornia crassipes plants. This is due to the fact that this weed and its ability to adapt as well as anthropogenic changes in the physicochemical composition of water sources have allowed it to invade and thrive in fresh water sources without $\mathrm{Al}$ in the concentrations evaluated, representing a risk for its growth. As a result, it was possible to understand that the evaluation of the growth of these plants under controlled conditions similar to those found in its natural habitat. This allowed us to infer that this weed is a very successful plant in the invasion of water sources given its ability to adapt to an unfavorable environment related to $\mathrm{Al}^{3+}$ toxicity. 


\section{ACKNOWLEDGEMENTS}

This study was funded by the Faculty of Agricultural Sciences at the Universidad Pedagógica y Tecnológica de Colombia (UPTC) with the help of the Plant Ecophysiology Research Group. The authors thank these institutions for their support.

\section{REFERENCES}

Abdullah, A.M. 2014. Aluminum pollution removal from water using a natural zeolite. Journal of Pollution Effects and Control 2:2. doi:10.4172/2375-4397.1000120.

Ali, S., Abbas, Z., Rizwan, M., Zaheer, I.E., Yavas, I., Unay, A., et al. 2020. Application of floating aquatic plants in phytoremediation of heavy metals polluted water: A review. Sustainability 12(5):1927. doi:10.3390/su12051927.

Almeida, O.N.D., Menezes, R.M., Nunes, L.S., Lemos, V.A., Luzardo, F.H.M., and Velasco, F.G. 2021. Conversion of an invasive plant into a new solid phase for lead preconcentration for analytical purpose. Environmental Technology and Innovation 21:101336. doi:10.1016/j.eti.2020.101336.

Ansari, A.A., Naeem, M., Gill, S.S., and AlZuaibr, F.M. 2020. Phytoremediation of contaminated waters: An ecofriendly technology based on aquatic macrophytes application. Egyptian Journal of Aquatic Research 46:371-376. doi:10.1016/j.ejar.2020.03.002.

Balsberg Pahlsson, A.M. 1990. Influence of aluminum on biomass, nutrients, soluble carbohydrate and phenols in beech (Fagus sylvatica). Physiologia Plantarum 78:79-84. doi:10.1111/j.1399-3054.1990.tb08718.x.

Berg, A. 1961. Rôle écologique des eaux de la cuvette congolaise sur la croissance de la jacinthe d'eau (Eichhornia crassipes) (Mart.) Solms. Mémoires Académie Royale des Sciences d'Outre-Mer, Classe des Sciences Naturelles et Médicalles Tome XII. Fasc. 3. 119 p. Available at http://www.kaowarsom.be/documents/MEMOIRES_VERHANDELINGEN/Sciences_ naturelles_medicales/Nat.Sc.(NS)_T.XII,3_BERG,\%20A._R\%C3\%B4le\%20\%C3\%A9cologique\%20des\%20eaux\%20 de $\% 201 \mathrm{a} \% 20$ cuvette $\% 20$ congolaise $\% 20$ sur\%20la\%20croissance $\% 20$ de $\% 201$ a $\% 20$ jacinthe\%20d'eau_1961.PDF.

Bialowiec, A., Albuquerque, A., and Randerson, P.F. 2014. The influence of evapotranspiration on vertical flow subsurface constructed wetland performance. Ecological Engineering 67:89-94. doi:10.1016/j.ecoleng.2014.03.032.

Broadley, M.R., White, P.J., and Hammond, J.P. 2007. Zinc in plants. New Phytologist 173:677-702. doi:10.1111/j.1469-8137.2007.01996.x.

Casierra-Posada, F., y Aguilar-Avendaño, O. 2007. Estrés por aluminio en plantas: reacciones en el suelo, síntomas en vegetales y posibilidades de corrección. Una revisión. Revista Colombiana de Ciencias Hortícolas 1(2):246-257. doi:10.17584/rcch.2007v1i2.8701.

Casierra-Posada, F., Cárdenas-Hernández, J., y Roa, H.A. 2008. Efecto del aluminio sobre la germinación de semillas de trigo (Triticum aestivum L.) y de maíz (Zea mayz L.) Orinoquia 12(1):45-56. https://www.redalyc.org/articulo.oa?id=89612105.

Casierra-Posada F., y Niño-Medina, R. 2007. Solubilidad y reacción del aluminio en el suelo. Ciencia y Agricultura 5(2):7-17. https://revistas.uptc.edu.co/index.php/ciencia_agricultura/article/view/308.

Colodetti, T.V., Nunes, W., Deleon, L., and Tomaz,M.A. 2015. Aluminum stress in Crambe abyssinica Hochst. Idesia 33(2):31-39. doi:10.4067/S0718-34292015000200004.

Dickson, W. 1978. Some effects of the acidification of Swedish lakes. Internationale Vereinigung für Theoretische und Angewandte Limnologie: Verhandlungen 20:851-856. doi:10.1080/03680770.1977.11896609.

Dorneles, A.O.S., Pereira, A.S., Sasso, V.M., Possebom, G., Tarouco, C.P., Schorr, M.R.W., et al. 2019. Aluminum stress tolerance in potato genotypes grown with silicon. Bragantia 78(1):12-25. doi:10.1590/1678-4499.2018007.

Freitas, L.B.D., Fernandes, D.M., Pivetta, L.A., and Maia, S.C.M. 2016. Tolerance of upland rice cultivars to aluminum and acidic pH.Revista Brasileira de Engenharia Agrícola e Ambiental 20(10):886-890. doi:10.1590/1807-1929/agriambi.v20n10p886-890.

Fu, W.G., and Wang, F.K. 2015. Effects of high soil lead concentration on photosynthetic gas exchange and chlorophyll fluorescence in Brassica chinensis L. Plant, Soil and Environment 61(7):316-321. doi:10.17221/306/2015-PSE.

Gensemer, R.W., and Playle, R.C. 1999. The bioavailability and toxicity of aluminum in aquatic environments. Critical Reviews in Environmental Science and Technology 29(4):315-450. doi:10.1080/10643389991259245.

Hodson, M.H. 2012. Metal toxicity and tolerance in plants. Biochemist 34(5):28-32. doi:10.1042/BIO03405028.

Hunt, R. 1990. Basic growth analysis. Plant growth analysis for beginners. Unwin Hyman Ltd., London, UK. doi:10.1007/978-94-010-9117-6.

Hunt, R., Causton, D.R., Shipley, B., and Askew, P. 2002. A modern tool for classical plant growth analysis. Annals of Botany 90(4):485-488. doi:10.1093/aob/mcf214.

Kabir, M., Iqbal, M.Z., Shafiq, M., and Farooqi, Z.R. 2010. Effects of lead on seedling growth of Thespesia populnea L. Plant, Soil and Environment 56(4):194-199. doi:10.17221/147/2009-PSE.

Ludwig, F., Guerrero, A.C., Fernandes, D.M., e Villas Boas, R.L. 2010. Análise de crescimento de gérbera de vaso conduzida em diferentes substratos. Horticultura Brasileira 28(1):70-74. doi:10.1590/S0102-05362010000100013. 
Maessen, M., Roelofs, J.G.M., Bellemakers, M.J.S., and Verheggen, G.M. 1992. The effects of aluminium, aluminium/ calcium ratios and $\mathrm{pH}$ on aquatic plants from poorly buffered environments. Aquatic Botany 43(2):115-127. doi:10.1016/0304-3770(92)90037-J.

Miladinova, K., Markovska, Y., Tzvetkova, N., Ivanova, K., Geneva, M., and Georgieva, T. 2014. Photosynthesis and growth response of two Paulownia hybrid lines to heavy metals Cd, Pb and Zn. Silva Balcanica 15(1):83-99.

Morales Velasco, S., Salazar Sánchez, M. 2012. Diatomeas perifíticas de lagos con diferente estado trófico en el departamento del Cauca (Colombia). Luna Azul 35:10-27. http://190.15.17.25/lunazul/downloads/Lunazul35_2.pdf.

Nascimento, S.M.D.S.G., Souza, A.P.D., Lima, V.L.A.D., Nascimento, C.W.A.D., and Nascimento, J.J.V.R.D. 2016. Phytoextractor potential of cultivated species in industrial area contaminated by lead. Revista Brasileira de Ciência do Solo 40:e0140805. doi:10.1590/18069657rbcs20140805.

Pereira, J.F. 2018. Initial root length in wheat is highly correlated with acid soil tolerance in the field. Scientia Agricola 75(1):79-83. doi:10.1590/1678-992X-2016-0422.

Pettersson, A., Hallbom, L., and Bergman, B. 1985. Physiological and structural responses of the cyanobacterium Anabaena cylindrica to aluminium. Physiologia Plantarum 63(2):153-158. doi:10.1111/j.1399-3054.1985 tb01895.x.

Rodríguez-Zambrano,A.P., y Aranguren-Riaño, N.J. 2014. Comunidad planctónica de un embalse con alta tensión ambiental: La Playa, cuenca alta del río Chicamocha (Tuta, Boyacá), Colombia. Biota Colombiana 15(2):95-110. http://revistas.humboldt. org.co/index.php/biota/article/view/323.

Sasaqi, D.,Pranoto,P., and Setyono, P. 2019. Estimation of water losses through evapotranspiration of water hyacinth (Eichhornia crassipes). Journal of Sustainable Agriculture 34(1):86-100. doi:10.20961/carakatani.v34i1.28214.

Sayago, U.F.C., Castro, Y.P., Rivera, L.R.C., and Mariaca, A.G. 2020. Estimation of equilibrium times and maximum capacity of adsorption of heavy metals by E.crassipes (review). Environmental Monitoring and Assessment 192:141. doi:10.1007/s10661-019-8032-9.

Sharma, P., Ngo, H.H., Khanal, S., Larroche, C, Kim, S.H., and Pandey, A. 2021. Efficiency of transporter genes and proteins in hyperaccumulator plants for metals tolerance in wastewater treatment: Sustainable technique for metal detoxification. Environmental Technology and Innovation 23:101725. doi:10.1016/j.eti.2021.101725.

Téllez, T., López, E.M., Granado, G., Pérez, E., López, R., and Sánchez Guzmán, J.M. 2008. The water hyacinth, Eichhornia crassipes: an invasive plant in the Guadiana River Basin (Spain). Aquatic 3(1):42-53. doi:10.3391/ai.2008.3.1.8.

Wang, C., He, J., Zhao, T.H., Cao, Y., Wang, G., Sun, B., et al. 2019. The smaller the leaf is, the faster the leaf water loses in a temperate forest. Frontiers in Plant Science 10:58. doi:10.3389/fpls.2019.00058.

Yates, M.J., Verboom, G.A., Rebelo, A.G., and Cramer, M.D. 2010. Ecophysiological significance of leaf size variation in Proteaceae from the Cape Floristic Region. Functional Ecology 24(3):485-492. doi:10.1111/j.1365-2435.2009.01678.x. 